\title{
The Impact of the US Political Pressure on RMB Exchange Rate: An Event Study Analysis
}

\author{
Wei Guo' ${ }^{1,2}$ \\ ${ }^{1}$ Department of Economics, College of Economics, Jinan University, Guangzhou, China \\ ${ }^{2}$ Department of Credit Management, Guangdong University of Finance, Guangzhou, China \\ Email: 602500326@qq.com
}

Received 27 July 2016; accepted 14 August 2016; published 17 August 2016

Copyright (C) 2016 by author and Scientific Research Publishing Inc.

This work is licensed under the Creative Commons Attribution International License (CC BY). http://creativecommons.org/licenses/by/4.0/

(c) (i) Open Access

\begin{abstract}
This paper takes the US as an example and uses event study approach to analyze the political events in which the US pressured RMB exchange rate between July 22, 2005 and March 31, 2016 as well as the outcomes of such actions, trying to reveal the influence of such events during the appreciation and depreciation period of RMB. The conclusions are as follows: 1) The pressure from the United States did not play a significant role in promoting RMB appreciation since only $53.4 \%$ out of 116 events between July 22, 2005 and March 31, 2016 were successful; 2) In various political events that aim at imposing pressure between July 22, 2005 and March 31, 2016, the US Congress had more significant influence on RMB exchange rate than the US administrative sectors; 3 ) Judging from the number of events, RMB exchange rate hasn't undergone obviously increased pressure from the US since its devaluation in 2014. However, unlike the situation in the appreciation stage, US administrative sectors were more influential than the Congress in the devaluation stage.
\end{abstract}

\section{Keywords}

Political Pressure, RMB Exchange Rate, Event Study

\section{Introduction}

After joining the World Trade Organization in 2001, China accumulates huge amounts of foreign exchange reserves through current-account surplus in foreign trade. After the exchange rate reform in July 2005, the currentaccount surplus has undergone even faster growth. Although the growth rate slowed down due to the international financial crisis between 2008 and 2011, the trend of surplus remained unchanged. According to the data from State Administration of Foreign Exchange (SAFE), China's current-account surplus reached 219.7 billion US dollars and the capital \& financial account surplus reached 38.2 billion US dollars in 2014. From the pers- 
pective of balance of payments, China's current-account surplus implies losses to the corresponding accounts of trading partners such as the United States. These trading partners tend to balance the revenue and expenditure account through issuance of debts, which would further aggravate the imbalance of economic structure, especially in the context of an international financial crisis. Therefore, the fluctuation of RMB exchange rate became the focus of concern and debate among countries like the United States.

In 2001, an article titled "China's Cheap Currency" was published in "Financial Times" and triggered hot debates among the international public over the revaluation of RMB. Since then, RMB exchange rate became a hot field of research in the international community and academia. In 2002, the Vice Finance Minister of Japan, Haruhiko Kuroda, and his Deputy Masahiro Kawai published the article "It's the Time for Global reflation" in "Financial Times", pointing out that China is exporting deflation to the world and putting forward the "China threat" theory. At the G7 finance minister conference in February of the same year, Japan's Finance Minister Masajuro Shiokawa submitted a bill to express the hope that finance ministers and central bank governors from the other six countries could put pressure on China and urge the revaluation of RMB. Masajuro Shiokawa accused the Chinese government of curbing the appreciation of RMB at the conference. He deemed the excessive undervaluation of RMB exchange rate as the direct cause of global deflation, demanding RMB appreciation by following the example of 1985 Japan-US "Plaza Accords". However, due to surpluses in the trade with China, Japan successfully got rid of continuing decline in the context of economic growth in Asia, which made it less imperative for Japan to call for revaluation of Renminbi. Since then, the United States became the major origin of pressure on appreciation of RMB. Especially after China surpassed Japan and became the largest origin of deficit for US in 2002, RMB exchange rate has aroused particular concern among American interest groups, congress and the government. Issues concerning exchange rate have also become an important means for US to push China in the new century. On the one hand, US administration officials like the President, Secretary of the Treasury and even the chairman of Fed have repeatedly stated that China needs to assume more responsibility in correcting global economic imbalances and pushing the unilateral appreciation of RMB through bilateral ("Strategic Economic Dialogue" (SED) and "Strategic and Economic Dialogue" (S\&ED)) and multilateral (IMF and the G20) mechanisms. On the other hand, US congressmen frequently propose motions or bills regarding RMB exchange rate, aiming at creating linkage between RMB exchange rate and Sino-US trade. It oppressed substantial and rapid RMB appreciation by threatening to impose anti-dumping duties and countervailing duties; or justifying the anti-dumping duties and countervailing duties on goods imported from China by accusing China of withholding RMB exchange rate to obtain unfair competitive advantages. The most prominent event is that the US Senate passed the "Currency Exchange Rate Oversight Reform Act of 2011" in October 2011, demanding the US government to investigate whether the exchange rates of major trading partners were undervalued. Then it determined to impose punitive tariffs, aiming at pushing the appreciation of RMB.

According to the statistics, RMB has appreciated more than 25\% against the US dollar since the reform of exchange rate system in 2005 until the end of 2013. Such substantial appreciation resulted from economic factors like strong economic growth over the years, continual accumulation of current-account surplus and inflows of foreign speculative capitals. But are there any political incentives other than economic factors behind the rapid appreciation of the RMB, especially the external political incentives from countries like US that force the appreciation of RMB all along? Some events seem to offer a clue to the answers. The first event is Paulson effect. Paulson effect refers to the phenomenon that former US Treasury Secretary Henry Paulson's three visits to China after assuming office triggered substantial appreciation of RMB three times. During Paulson's first visit in September 2006, the RMB exchange rate successively broke three integer marks-7.94, 7.93 and 7.92—in four days, which hit a new high. Between 14th and 15th December of the same year, Paulson paid the second visit to China and led a delegation to carry out SED. The central parity rate of RMB exchange rate exceeded the 7.82 mark for the first time and reached the level of 7.8197. During the third visit to China, the RMB exchange rate approached the 7.74 mark and once again hit a new high since the reform of exchange rate system. The second event is the 2012 US presidential election. During the US presidential election in 2012, the final candidates Barack Obama and Romney successively condemned each other for adopting overly weak China policy. In the meantime, the yuan-dollar exchange rate underwent eight consecutive limits under great upward pressure. Although the Chinese government repeatedly stressed the independence of the RMB exchange rate policy and denied the impact of foreign political pressure on changes in the exchange rate. In an official declaration of foreign policy, such a statement is particularly necessary and understandable. However, from an academic point of view, we need to use economic methodology to further reveal the causes of external political pressure and the 
specific impact of impellent events on the RMB exchange rate. This paper takes U.S. as the primary pusher and uses event study approach to analyze the political events between July 22, 2005 and March 31, 2016 in which the United States put pressure on RMB exchange rate and outcomes of such actions, trying to reveal the influence of such events during the appreciation and depreciation of RMB.

\section{Literature Review}

In recent years, the scholars have tried different theories and empirical research methods to verify the relevance between RMB appreciation and external political pressure. Li Zenggang, Dong Liwa (2005) studied Renminbi exchange rate under framework of Two-Level Game, which indicates the issue of currency contains complicated political and economical factors, the decision of Renminbi exchange rate involves game between countries, game between interest groups, and game between interest groups and the government [1]. Xiao Ting and Wang Yan (2012) analyzed the Sino-US disputes over exchange rate from the perspective of evolutionary game theory [2]. They found that in the face of external appreciation pressure, the Chinese government's attitude towards RMB exchange rate experienced a transition from unchanged exchange rate, accelerated appreciation, slight appreciation and finally to the long-term and slow appreciation. Li Zilian (2011) constructed a panel data variable coefficient model which takes the RMB exchange rate against currencies of different countries as the explained variables and political variables including interest groups, election cycle, political parties and factions as well as the bills of US House and Senate as major explanatory variables. After empirical analyses on the data of United States, Japan, Britain, Germany and France between 1995 and 2009, the study concluded that: factors like interest groups, election cycle as well as political parties and factions contribute to the appreciation of RMB [3]. Han Huichao, Xu Kangning (2014 constructed a Pro-bit model to analyze "Exchange rate reform to promote fair trade act" from the U.S. congress in 2010, empirical result shows that pressures put on China for Renminbi appreciation is the consequence of game between interest groups, members of congress and voters [4]. Zhang Xin, Cui Yanjuan, Sun Gang (2015) started from the perspective of political games, studied the impact of foreign governments and the Chinese government on Renminbi exchange rate, they found that game between governments has significant influence on Renminbi exchange rate, since the foreign governments stay in the advantage positions in the game, the pressures put on Renminbi has significantly promoted the appreciation of Renminbi [5]. Zhu Mengnan et al. (2015) established a "Political Cycle Spillover Effect Model” by taking the US political cycle as the most critical political factor and analyzing the transmission mechanism between political cycle and RMB exchange rate. They conducted empirical analyses and found that: US political cycle has a direct short-term impact on the RMB exchange rate and such impact is mainly transmitted through capital flows and policy control; the RMB appreciation rate would show cyclical variations along with the US presidential election and mid-term election: the RMB appreciation rate would significantly decrease in the first year after the US President assumes office and undergo sharp increase in the first year after the mid-term election [6]. Inspired by events like "Paulsen effect", some scholars began to focus on different events that affect the fluctuation of RMB exchange rate through external political pressure. For example, Frankel \& Wei (2007) collected news from mainstream US newspapers about the United States putting pressure on RMB and analyzed whether the US political pressure enhances the flexibility of RMB's daily return. The results indicated that the US political pressure showed no significant influence between July 1, 2005 and January 8, 2007 after other factors in the currency basket were controlled [7]. Liu and Laurent (2012) collected news concerning RMB from mainstream US newspapers and built some political indicators. They found that US political pressure and non-US political pressure had insignificant influence on RMB's daily return between July 2005 and May 2011; however RMB's conditional volatility is subject to external political pressure [8]. Liu Tao and Zhou Jizhong (2011) focused on investigating the effect of pressure from US Government and Congress. They used "classification event study" to investigate the impact of US political pressure on RMB appreciation between 2005 and 2010 and pointed out that: although the impact of US political pressure on RMB appreciation is generally insignificant, the impact would become more significant when RMB remains fixed or devaluates; the pressure from US legislation branches is more effective than that form governmental sectors [9]

The existing literatures studied the impacts on determination and fluctuation of RMB exchange rate from the perspective of game theory, domestic political factors of countries that impose pressure or external political events, which provides people with new angles to better understand the determination mechanism and fluctuation of exchange rate. However, the relevant researches still have some drawbacks for the lack of a mature re- 
search system during the development stage: Firstly, the existing literatures' definition of external events is unclear. The majority of studies adopt the classification of legislative and administrative sector without classification and analysis of specific sources within two sectors; secondly, most studies were simply focused on whether external political pressure caused the appreciation of RMB. They didn't study the devaluation period after February 2014 or analyze the existence and results of impellent events in such period. This paper attempts to overcome these shortcomings in the study. It firstly carries out rigorous and systematic definition and classification of the pressure from US; Secondly, it covers the depreciation period after 2014, observing whether the external political pressure remains when devaluation became the norm and the effects of such pressure.

\section{Event Study Approach}

"Event study" was first put forward by James and Dolley in 1933 when they were examining the price effects of stock splits. The principle is using event study approach to observe the impact of specific economic or political events on changes in stock price or stock yield, so as to explain part of the reasons why stock price or stock yield fluctuates in a short term. Subsequently, the scholars began to use it in economic and financial areas. In the studies on exchange rates, event study is mainly used to research the effects of governmental intervention in foreign exchange market on fluctuations of exchange rates. Scholars have adopted this method to observe the influence of governmental interventions in the exchange market (usually monetary sterilization events like buying or selling) on exchange rates. Neely (2005) [10] divided relevant literatures into three classes according to differences in the application of event study: time series event study, other event study methods and well-defined structure analysis event study. In recent years, the scholars are still trying different event study methods to research the effects of external political events on the RMB exchange rate. For example, Liu and Laurent (2012) applied the time series event study method; built some political pressure indicators that pressure RMB; used GARCH model to conduct empirical analysis of the external pressure's influence on RMB's daily returns and conditional volatility. Liu Tao (2011) adopted the "classification event study" which includes means like nonparametric sign test, paired sample test and predictive value test to investigate whether US political pressure pushes the appreciation of RMB.

Considering the difficulties in quantifying external political events; that the events are sporadic and clustered; and that varied types of events require specific classification and definition, this paper adopts the concept of "classification event study method" proposed by Liu Tao (2011) to distinguish from the "time series event study method" and highlight that the political events are complex in type and need more specific classification and definition. The specific steps are as follows: 1) Define the events, 2) Define the time window of events, 3) Define the criteria for successful events, 4) Make assessments of the successful events.

\subsection{Define the Events}

The definition of political events plays a very important part in researches on the impact of external pressure on RMB exchange rate and the extent of such pressure. However the existing literatures have had different definitions of political impellent events. Liu and Laurent (2012), searched headlines with the keyword "RMB appreciation" and "RMB exchange rate flexibility" in both Bloomberg and Reuters news database, included foreign dignitaries' comments relating to RMB in official and non-official occasion into the event statistics, and collected 213 events between May 30, 2011 and July 22, 2005; Hu Zaiyong (2013) modelled on the practice of Liu and replaced the Chinese databases. He searched the keyword "putting pressure" and "RMB" in the Chinese Biz Serial Database and Chinese Newspaper Resources Full-text Database, finding 256 events between August 31, 2011 and July 22, 2005 [11]; While Liu Tao (2010) defined impellent events as the official, formal, and public pressure, including events such as US legislative branches' official motions and hearings, official high-level meetings, and the twice-yearly exchange rate policy report from Ministry of Finance. He captured 53 events between July 2005 and October 2010, all of which were divided into legislative and the administrative ones. This paper defines political impellent events as the official, formal, and public pressure including US Congress's motions and hearings with respect to RMB exchange rate, Sino-US heads meetings, US Treasury Secretary's visits to China, the release of reports on international economy and exchange rate policy, SED and S\&ED Conferences, as well as China-US Joint Commission on Commerce and Trade (JCCT). It collected a total of 116 events between July 22, 2005 and March 31, 2016. Secondly, events like congress motions and hearings, the release of reports on international economy and exchange rate policy generally occur in one day; while events like 
Sino-US heads meetings, US Treasury Secretary's visits to China and Sino-US bilateral conferences usually last for a few days. This paper defines both of them as separate events. On the other hand, as for coincidence of events, (for example, the 2007 SED meeting, JCCT and the release of reports on international economy and exchange rate policy all took place between December 11th and 19th) this paper combines multiple events into an event period. A total of 107 events periods were finally obtained in this way.

\subsection{Define the Pre- and Post-Event Windows}

Define the time window of events means to set the length of event periods. The length of event periods would affect the accurate understanding of events' impacts on the exchange rate at a specific time. It may be difficult to fully capture the impact of events on exchange rate if the window is too short; if the window is too long, the coincidence of events may cause interference among events, which makes it impossible to observe the influence from a particular event. In the existing literatures, Rasmus Fatum \& Michael m. Hutchison (2003) [12], Pierdzioch \& Stadtmann (2004) [13] and Liu Tao (2010) all used 2 days as the window length to avoid overlap. After observing 107 event periods during the sample period, this paper decided to take 2 business days when the $\mathrm{RMB} / \mathrm{USD}$ exchange rate is released as the window length, that is, to contrast the exchange rate fluctuations 2 days before and after the event period during the evaluation of event effects, and require at least 2 pre-event (after-event) windows (4 bilateral exchange rate published days) between 2 separate events.

\subsection{Define a Successful Event}

In the studies of political pressure's influence on the RMB exchange rate, the successful event means that fluctuations of RMB exchange rate meet the expected effect of a political impellent event, which generally speaking, is the result of RMB appreciation. However, the changes in exchange rates are quite complex in reality and there're also various forms of successful events. Therefore, it is necessary to develop criteria of "success" before contrasting changes in RMB's daily return in the pre-event and after-event window to better observe the impacts of external political pressure on RMB. With reference to the success criteria proposed by Neely (2005), Rasmus Fatum and Michael M. Hutchison (2003), Marcel Fratzscher (2005) [14], and Liu Tao (2010), this paper adopts the follows success criteria, see Table 1.

\section{Analysis of the Assessment Results}

This paper uses event study approach to assess the impact on RMB from US political pressure between 22 July 2005 and 31 March 2016. RMB's daily return is taken as the RMB exchange rate: $r_{t}=\left(\ln s_{t}-\ln s_{t-1}\right) \times 100 \%$, $s_{t}$ refers to the RMB/USD exchange rate. As for the subject of events, the political events are divided into those initiated by the legislative branches and by the administrative departments. The events initiated by legislative branches mainly include US Congress's motions and hearings in connection with RMB exchange rate; while the events initiated by administrative departments include Sino-US heads meetings, US Treasury Secretary' s visits to China, reports on international economy and exchange rate policy, SED and S\&ED Conferences, as well as China-US Joint Commission on Commerce and Trade(JCCT). The data sources of abovementioned events are listed in Table 2.

\subsection{Results of Assessment on Classified Events}

By applying the event study method and the definitions discussed above, political events from United States

Table 1. Success criteria of events.

\begin{tabular}{|c|c|c|}
\hline Success criteria & RMB's daily return before and after the event & Explanation \\
\hline Reversal & $\Delta S_{\text {pre }}>0, \Delta S_{\text {post }}<0$ & $\begin{array}{l}\text { Reversal means that RMB was devaluating before the event } \\
\text { and switched to the state of appreciation after the event. }\end{array}$ \\
\hline Smoothing & $\Delta S_{\text {pre }}>0, \Delta S_{\text {post }}>0$ and $\Delta S_{\text {post }}<\Delta S_{\text {pre }}$ & $\begin{array}{l}\text { Smoothing means that RMB was devaluating before the event } \\
\text { and the depreciation mitigated after the event despite the con- } \\
\text { tinued trend of depreciation. }\end{array}$ \\
\hline Enlarging & $\Delta S_{\text {pre }}<0, \Delta S_{\text {post }}<0$ and $\Delta S_{\text {post }}<\Delta S_{\text {pre }}$ & $\begin{array}{l}\text { Enlarging means that RMB was undergoing appreciation be- } \\
\text { fore the event, then the appreciation continued and enlarged } \\
\text { after the event. }\end{array}$ \\
\hline
\end{tabular}


Table 2. Data sources.

\begin{tabular}{|c|c|c|}
\hline Event & Data sources & Key words \\
\hline Congress(motion) & $\begin{array}{l}\text { https://www.congress.gov/ } \\
\text { http://thomas.loc.gov/home/thomas.php }\end{array}$ & $\begin{array}{l}\text { Exchange rate, currency, China, exchange rate manipulation, } \\
\text { exchange rate intervention, undervalue currency }\end{array}$ \\
\hline Congress(hearing) & $\begin{array}{l}\text { Committee on Ways and Means, Committee } \\
\text { on Finance websites: } \\
\text { http://waysandmeans.house.gov/ } \\
\text { http://www.finance.senate.gov/hearings }\end{array}$ & $\begin{array}{l}\text { exchange rate, currency, China, exchange rate manipulation, } \\
\text { exchange rate intervention, undervalue currency }\end{array}$ \\
\hline Sino-US heads meeting & $\underline{\text { www.baidu.com }}$ & Sino-US heads meeting, US president's visit to China \\
\hline $\begin{array}{l}\text { US treasury secretary's visit } \\
\text { to China }\end{array}$ & $\underline{\text { www.baidu.com }}$ & US treasury secretary's visit to China \\
\hline $\begin{array}{l}\text { Report on international } \\
\text { economy and exchange rate } \\
\text { policy }\end{array}$ & $\begin{array}{l}\text { The U.S. Treasury Department's website: } \\
\text { https://www.treasury.gov/Pages/default.aspx }\end{array}$ & $\begin{array}{l}\text { Report to Congress } \\
\text { on International Economic and Exchange Rate; } \\
\text { International Economic and exchange rate report }\end{array}$ \\
\hline SED, S\&ED & $\begin{array}{l}\text { The U.S. Treasury Department's website: } \\
\text { https://www.treasury.gov/Pages/default.aspx }\end{array}$ & $\begin{array}{l}\text { Strategic Economic Dialogue (SED); } \\
\text { U.S. China Strategic and Economic Dialogue (S\&ED) }\end{array}$ \\
\hline JCCT & $\underline{\text { www.baidu.com }}$ & JCCT \\
\hline
\end{tabular}

SED (Strategic Economic Dialogue) was renamed as S\&ED (Strategic and Economic Dialogue) in 2009.

between 22 July 2005 and 31 March 2016 which concerning RMB exchange rate are classified and assessed in the following table, see Table 3.

\subsection{Analysis of Assessment Results}

\subsubsection{General Analysis}

See Figure 1. According to the definition of events in this paper, there were 116 events between July 22, 2005 and 31 March 2016 in which the United States put pressure on RMB, wherein 51 events were initiated by the US Congress and 65 events by US administrations. In exclusion of 2005 and 2016 with incomplete number of events, 2011, 2007, and 2010 are the most eventful years; four years with the highest success rates are respectively 2008 (75\%), 2015 (66.67\%), 2011 (60\%) and 2013 (60\%). 58 out of 107 event periods are in line with the "success" criteria, accounting for about $54.2 \%$ in the total number of events. It is worth noting the difference between events and event periods, part of the event periods contain two or more events. Since the influence of these events on RMB is inseparable from each other, they are included into one event period. However, there is a possibility that multiple events in the same event period successfully affected the RMB exchange rate. There are totally 62 independent events in this sample, which means at most 62 events could be successful from the viewpoint of event count. Nevertheless, the highest success ratio does not exceed 53.4\%. The following statistics are all conducted in the way of event count for ease of classification, namely regarding all independent events in the successful event period as successful events. Therefore, there are totally 116 events during the sample period.

\subsubsection{Analysis of Successful Events}

See Figure 2. The successful events accounted for $56.9 \%$ in all events started by US Congress (29 out of 51 events succeeded) and $50.8 \%$ in those started by US administrations (33 out of 65 events succeeded). Among six categories of administrative political events, US Treasury Secretary's visits to China and the semiannual report on international economy and exchange rate policy released by US Treasury Department imposed more effective pressure on RMB. The success rate of US Treasury Secretary's visits to China was $57.1 \%$ (8 out of 14 events succeeded), while the success rate of report on international economy and exchange rate policy was as much as $68.4 \%$ (13 out of 19 events succeeded).

\subsubsection{Analysis of Reversal Events}

See Figure 3. Among all three standards of successful events, the "reversal"-RMB was devaluating before the events and switched to the state of appreciation after the event-is the most effective and persuasive event, so this paper also analyze the sources of reversal events. There're totally 28 reversal events during the sample period. US Congress and Administrations respectively started 14 events. "Reversal" accounted for $27.5 \%$ in all 
Table 3. Results of assessment on classified events.

\begin{tabular}{|c|c|c|c|c|}
\hline Serial No. & Event period & Nature of events & Successful or not & Success criteria \\
\hline 1 & $05-10-6$ & Congress & $\sqrt{ }$ & Reversal \\
\hline 2 & $05-10-20$ & Congress & $\sqrt{ }$ & Smoothing \\
\hline 3 & $05-11-21$ & Sino-US heads meeting & $\sqrt{ }$ & Enlarging \\
\hline 4 & $05-11-28$ & Report on international economy and exchange rate policy & & $\mathrm{X}$ \\
\hline 5 & $06-2-16$ & Congress & $\sqrt{ }$ & Reversal \\
\hline 6 & $06-3-2$ & Congress & & $\mathrm{X}$ \\
\hline 7 & $06-3-8 \sim 9$ & Congress & $\sqrt{ }$ & Smoothing \\
\hline 8 & $06-4-11$ & JCCT & & $\mathrm{X}$ \\
\hline 9 & 06-4-18 21 & Sino-US heads meeting & & $\mathrm{X}$ \\
\hline 10 & $06-5-10$ & Report on international economy and exchange rate policy & & $\mathrm{X}$ \\
\hline 11 & 06-9-19 28 & US treasury secretary's visit to China/Congress & & $\mathrm{X}$ \\
\hline 12 & 06-12-14 15 & US treasury secretary's visit to China & & $\mathrm{x}$ \\
\hline 13 & 06-12-19 & Report on international economy and exchange rate policy & $\sqrt{ }$ & Enlarging \\
\hline 14 & $07-1-9$ & Congress & $\sqrt{ }$ & Reversal \\
\hline 15 & $07-1-23$ & Congress & $\sqrt{ }$ & Reversal \\
\hline 16 & $07-1-31$ & Congress & $\sqrt{ }$ & Reversal \\
\hline 17 & $07-2-12 \sim 28$ & Congress & & $\mathrm{x}$ \\
\hline 18 & $07-3-7 \sim 8$ & Congress/US Treasury Secretary's visit to China & & $\mathrm{X}$ \\
\hline 19 & $07-3-27 \sim 28$ & Congress & $\sqrt{ }$ & Reversal \\
\hline 20 & $07-5-9$ & Congress & $\sqrt{ }$ & Enlarging \\
\hline 21 & $07-5-16 \sim 23$ & SED & $\sqrt{ }$ & Smoothing \\
\hline 22 & 07-6-13 & Congress & & $\mathrm{x}$ \\
\hline 23 & $07-6-28$ & Congress & $\sqrt{ }$ & Reversal \\
\hline 24 & $07-7-16$ & Congress & $\sqrt{ }$ & Reversal \\
\hline 25 & $07-7-26 \sim 8-2$ & US treasury secretary's visit to China & $\sqrt{ }$ & Enlarging \\
\hline 26 & 07-12-11 19 & $\begin{array}{l}\text { JCCT/SED/Report on international economy and exchange rate } \\
\text { policy }\end{array}$ & & $\mathrm{X}$ \\
\hline 27 & $08-4-2 \sim 3$ & Congress/US treasury secretary's visit to China & $\sqrt{ }$ & Enlarging \\
\hline 28 & $08-5-16$ & Report on international economy and exchange rate policy & $\sqrt{ }$ & Reversal \\
\hline 29 & $08-6-17 \sim 18$ & SED & & $\mathrm{X}$ \\
\hline 30 & $08-8-7 \sim 8$ & Sino-US heads meeting & & $\mathrm{X}$ \\
\hline 31 & 08-9-16 & JCCT & $\sqrt{ }$ & Reversal \\
\hline 32 & $08-12-4 \sim 10$ & $\begin{array}{l}\text { Report on international economy and exchange rate poli- } \\
\text { cy/SED }\end{array}$ & $\sqrt{ }$ & Enlarging \\
\hline 33 & 09-1-13 14 & Congress & & $\mathrm{X}$ \\
\hline 34 & 09-4-15 & Report on international economy and exchange rate policy & & $\mathrm{X}$ \\
\hline 35 & 09-5-13 & Congress & $\sqrt{ }$ & Smoothing \\
\hline 36 & $09-6-1 \sim 2$ & S\&ED/US Treasury Secretary's visit to China & & $\mathrm{x}$ \\
\hline 37 & 09-6-11 & Congress & & $\mathrm{x}$ \\
\hline 38 & $09-7-27 \sim 28$ & S\&ED & & $\mathrm{X}$ \\
\hline 39 & 09-10-15 & Report on international economy and exchange rate policy & $\sqrt{ }$ & Reversal \\
\hline 40 & $09-10-29$ & JCCT & & $\mathrm{X}$ \\
\hline 41 & 09-11-15 18 & Sino-US heads meeting & & $\mathrm{X}$ \\
\hline
\end{tabular}




\section{Continued}

\begin{tabular}{|c|c|c|c|c|}
\hline 42 & $10-3-17$ & Congress & & $\mathrm{X}$ \\
\hline 43 & $10-3-24$ & Congress & & $\mathrm{X}$ \\
\hline 44 & $10-4-8$ & S\&ED & & $\mathrm{X}$ \\
\hline 45 & $10-5-24 \sim 25$ & S\&ED & $\sqrt{ }$ & Enlarging \\
\hline 46 & $10-6-10 \sim 17$ & Congress & $\sqrt{ }$ & Enlarging \\
\hline 47 & $10-6-23$ & Congress & $\sqrt{ }$ & Enlarging \\
\hline 48 & $10-7-8$ & Report on international economy and exchange rate policy & $\sqrt{ }$ & Reversal \\
\hline 49 & $10-7-30$ & Congress & & $\mathrm{X}$ \\
\hline 50 & $10-9-15 \sim 29$ & Congress & & $\mathrm{X}$ \\
\hline 51 & $10-10-24$ & US treasury secretary's visit to China & $\sqrt{ }$ & Smoothing \\
\hline 52 & $10-12-15$ & JCCT & $\sqrt{ }$ & Smoothing \\
\hline 53 & $11-1-18 \sim 21$ & Sino-US heads meeting & & $\mathrm{X}$ \\
\hline 54 & $11-2-14$ & Congress & $\sqrt{ }$ & Reversal \\
\hline 55 & $11-4-6$ & Congress & $\sqrt{ }$ & Enlarging \\
\hline 56 & $11-5-9 \sim 10$ & S\&ED & & $\mathrm{X}$ \\
\hline 57 & $11-5-27$ & Report on international economy and exchange rate policy & $\sqrt{ }$ & Enlarging \\
\hline 58 & $11-6-16$ & Congress & $\sqrt{ }$ & Enlarging \\
\hline 59 & $11-6-21$ & Congress & & $\mathrm{X}$ \\
\hline 60 & $11-9-13$ & Congress & $\sqrt{ }$ & Reversal \\
\hline 61 & $11-9-26$ & Congress & $\sqrt{ }$ & Reversal \\
\hline 62 & 2011-10-3 6 & Congress & & $\mathrm{X}$ \\
\hline 63 & 2011-10-11 14 & Congress & & $\mathrm{X}$ \\
\hline 64 & $11-10-18$ & Congress & & $\mathrm{X}$ \\
\hline 65 & $2011-10-25 \sim 26$ & Congress & & $\mathrm{X}$ \\
\hline 66 & 2011-11-2 3 & Congress & $\sqrt{ }$ & Enlarging \\
\hline 67 & $11-11-21$ & JCCT & $\sqrt{ }$ & Reversal \\
\hline 68 & $11-11-25$ & Congress & $\sqrt{ }$ & Enlarging \\
\hline 69 & $11-12-6$ & Congress & $\sqrt{ }$ & Enlarging \\
\hline 70 & $11-12-12$ & Congress & & $\mathrm{X}$ \\
\hline 71 & $11-12-16$ & Congress & $\sqrt{ }$ & Reversal \\
\hline 72 & $11-12-27$ & Report on international economy and exchange rate policy & $\sqrt{ }$ & Enlarging \\
\hline 73 & 2012-1-10 11 & US treasury secretary's visit to China & $\sqrt{ }$ & Reversal \\
\hline 74 & 2012-2-13 17 & Sino-US heads meeting & $\sqrt{ }$ & Reversal \\
\hline 75 & $12-2-29$ & Congress & & $\mathrm{X}$ \\
\hline 76 & 2012-5-2 3 & S\&ED & & $\mathrm{X}$ \\
\hline 77 & $12-5-25$ & Report on international economy and exchange rate policy & $\sqrt{ }$ & Smoothing \\
\hline 78 & $12-6-7$ & Congress & & $\mathrm{X}$ \\
\hline 79 & 2012-8-15 16 & Congress & $\sqrt{ }$ & Enlarging \\
\hline 80 & $12-11-17$ & Report on international economy and exchange rate policy & $\sqrt{ }$ & Reversal \\
\hline 81 & $12-12-5$ & US treasury secretary's visit to China & & $\mathrm{X}$ \\
\hline 82 & $12-12-19$ & JCCT & & $\mathrm{X}$ \\
\hline 83 & 2013-3-19 20 & US treasury secretary's visit to China/Congress & $\sqrt{ }$ & Smoothing \\
\hline 84 & $13-4-12$ & Report on international economy and exchange rate policy & $\sqrt{ }$ & Enlarging \\
\hline 85 & 2013-6-7 8 & Congress/Sino-US heads meeting & $\sqrt{ }$ & Smoothing \\
\hline
\end{tabular}




\begin{tabular}{|c|c|c|c|c|}
\hline \multicolumn{5}{|c|}{ Continued } \\
\hline 86 & 2013-7-10 11 & S\&ED & & $\mathrm{X}$ \\
\hline 87 & 13-7-17 & Congress & & $\mathrm{X}$ \\
\hline 88 & $13-10-30$ & Report on international economy and exchange rate policy & $\sqrt{ }$ & Smoothing \\
\hline 89 & 2013-11-15 16 & US treasury secretary's visit to China & & $\mathrm{X}$ \\
\hline 90 & 2013-12-19 20 & JCCT & & $\mathrm{X}$ \\
\hline 91 & $14-1-15$ & Congress & & $\mathrm{X}$ \\
\hline 92 & $14-4-15$ & Report on international economy and exchange rate policy & $\sqrt{ }$ & Reversal \\
\hline 93 & 14-5-13 & US treasury secretary's visit to China & $\sqrt{ }$ & Smoothing \\
\hline 94 & 14-6-25 & Congress & $\sqrt{ }$ & Reversal \\
\hline 95 & 2014-7-9 10 & S\&ED & & $\mathrm{X}$ \\
\hline 96 & $14-10-15$ & Report on international economy and exchange rate policy & & $\mathrm{X}$ \\
\hline 97 & 2014-12-16 18 & JCCT & & $\mathrm{X}$ \\
\hline 98 & 2015-2-10 12 & Congress & & $\mathrm{X}$ \\
\hline 99 & 2015-3-28 31 & US treasury secretary's visit to China & $\sqrt{ }$ & Reversal \\
\hline 100 & $15-4-9$ & Report on international economy and exchange rate policy & & $\mathrm{X}$ \\
\hline 101 & $15-4-29$ & SED & $\sqrt{ }$ & Smoothing \\
\hline 102 & 15-5-18 & Congress & $\sqrt{ }$ & Reversal \\
\hline 103 & 2015-6-23 24 & S\&ED & & $\mathrm{X}$ \\
\hline 104 & 2015-9-22 27 & Sino-US heads meeting & $\sqrt{ }$ & Reversal \\
\hline 105 & $15-10-19$ & Report on international economy and exchange rate policy & $\sqrt{ }$ & Reversal \\
\hline 106 & 2015-11-21 23 & JCCT & $\sqrt{ }$ & Reversal \\
\hline 107 & 2016-2-28 29 & US treasury secretary's visit to China & $\sqrt{ }$ & Reversal \\
\hline
\end{tabular}

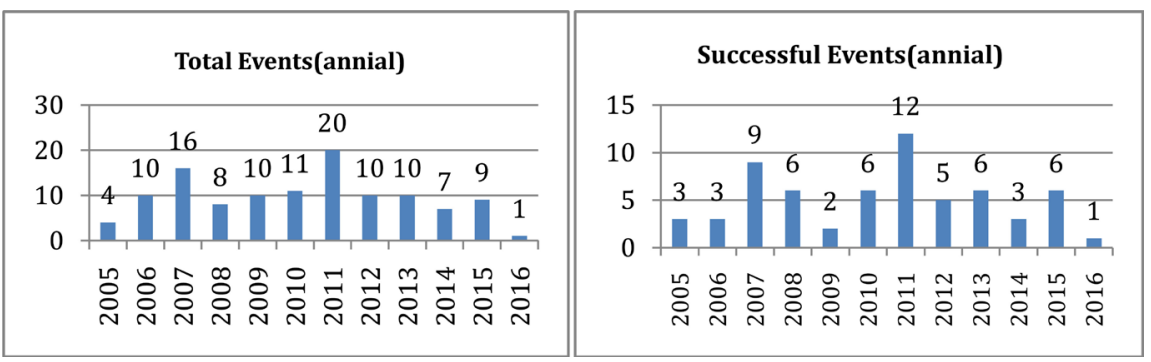

Figure 1. Total events and successful events from 2005.7.22 to 2016.3.31.

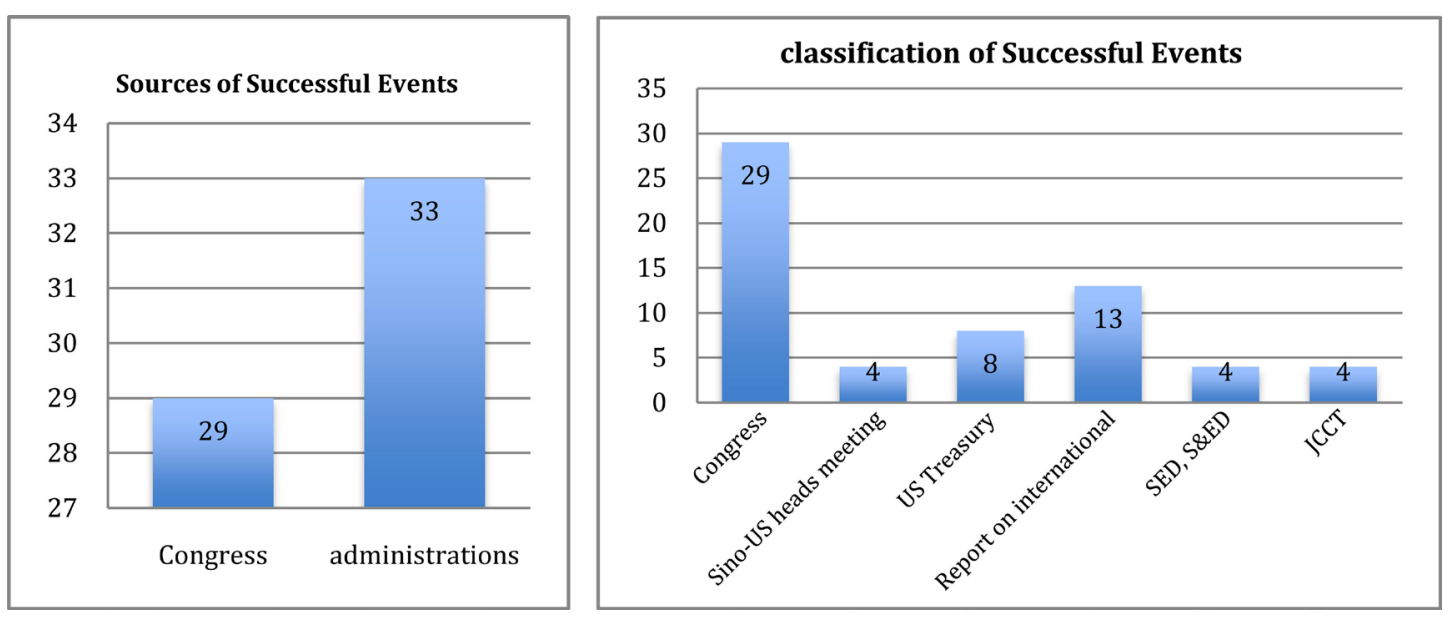

Figure 2. Sources of successful events, classification of successful events from 2005.7.22 to 2016.3.31. 

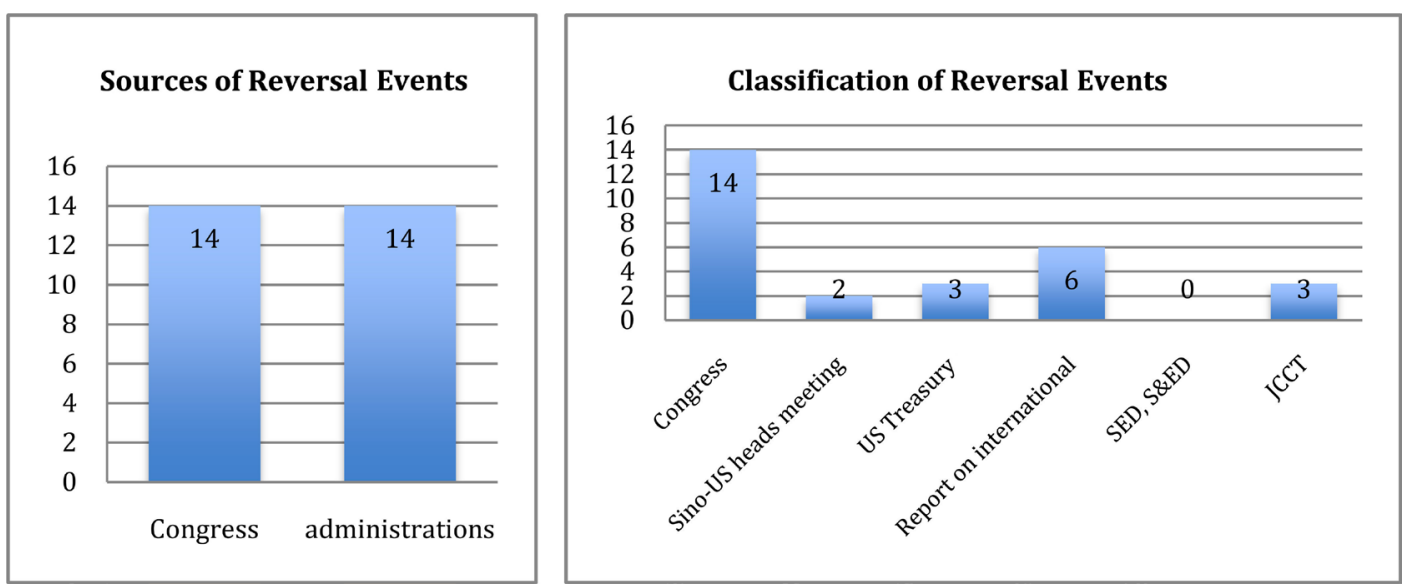

Figure 3. Sources of reversal events, classification of reversal events.

congress events (14 out of 51 events) and 21.5\% in the administration events (14 out of 65 events). Furthermore, among six categories of administrative political events, US Treasury Secretary's visits to China and the semiannual report on international economy and exchange rate policy released by US Treasury Department showed a "reversal rate" of 31.6\% (6 out of 19 events), while the pressure from JCCT showed a "reversal rate" of 30\% (3 out of 10 events).

Generally speaking, the United States started a total of 116 events between July 2005 and March 2016 to pressure RMB, and $53.4 \%$ of these events succeeded in affecting RMB exchange rate; as for the subject of pressure, US congressional sectors played a more effective role in pressuring RMB exchange rate in comparison to administrative sectors; as for the pressure from administrative sectors, US Treasury Secretary's visits to China, the release of semiannual report on international economy and exchange rate policy, and the JCCT had relatively stronger effects on RMB exchange rate.

\section{Concluding Comments}

Firstly, the conclusions of this paper are similar to the study results of Frankel and Wei (2007), Liu and Laurent (2012), Liu Tao and Zhou Jizhong (2011) despite the extended length of sample period and improved methods to classify events. Since only $53.4 \%$ out of 116 events succeeded and merely $24.14 \%$ events achieved reversal effect (turned devaluation into appreciation), this paper similarly concludes that the pressure from United States does not play a significant role in promoting RMB appreciation.

Secondly, among various political impellent events, the US Congress had more significant influence on RMB exchange rate than administrative sectors. Although US Congress usually plays the role of regulator in exchange rate policies, the impact of motions, bills proposed by both houses as legislatures and related hearings on RMB exchange should never be underestimated; as for the pressure from administrative sectors, the semiannual report on international economy and exchange rate policy, the JCCT and US treasury secretary's visits to China had relatively stronger effects on RMB exchange rate.

Finally, judging from the number of events, RMB exchange rate hasn't undergone obviously increased pressure from US since its devaluation in 2014. From the perspective of success rate, only 2015 showed a higher success rate of $66.67 \%$ among three years during the depreciation stage. It's worth noting that unlike the situation in the appreciation stage, US administrative sectors were more influential than the Congress in the devaluation stage; in the administrative events, US treasury secretary's visits to China and the release of semiannual report on international economy and exchange rate policy had more significant influence on RMB exchange rate.

\section{References}

[1] Li, Z.G. and Dong, L.W. (2005) The International Political Economics of Exchange Rate Determination. Journal of Guangdong University of Finance, No. 11, 44-51.

[2] Xiao, T. and Wang, Y. (2012) An Analysis of US-China Debates on Renminbi Exchange Rate Based on the Evolutionary Game Theory. Southwest Finance, No. 3, 39-41. 
[3] Li, Z.L. (2011) Politics and Exchange Rate: Political Economics Analysis of RMB Appreciation. World Economics and Politics, No. 9, 136-160.

[4] Han, H.C. and Xu, K.N. (2014) The Political Economics Analysis of US Pressure on Renminbi Exchange Rate. Contemporary Finance \& Economics, No. 4, 5-13.

[5] Zhang, X., Cui, Y.J. and Sun, G. (2015) Look from the Dual Exchange Rate of RMB Exchange Rate-Is China really a Currency Manipulator? Finance \& Trade Economics, No. 7, 32-43.

[6] Zhu, M.N., Zhao, Q. and Wang, Y.G. (2015) The Incentive of RMB Exchange Rate Fluctuation: Base on the Assessment of US Political Cycle’s Spillover Effect. Management World, No. 4, 38-51.

[7] Frankel, J.A. and Wei, S. (2007) Assessing China’s Exchange Rate Regime. Economic Policy, No. 51, 575.

[8] Liu, L. and Pauwels, L.L. (2012) Do External Political Pressures Affect the Renminbi Exchange Rate? Journal of International Money and Finance, 31, 1800-1818. http://dx.doi.org/10.1016/j.jimonfin.2012.04.001

[9] Liu, T. and Zhou, J.Z. (2011) Do External Pressures Promote the Appreciation of Renminbi? Base on the Assessment of US Impellent Events' Outcomes between 2005 and 2010. Journal of Financial Research, No. 11, 32-46.

[10] Neely, C.J. (2005) An Analysis of Recent Studies of the Effect of Foreign Exchange Intervention. Working Papers 2005-030, Federal Reserve Bank of St. Louis.

[11] Hu, Z.Y. and Liu, S.G. (2013) Do External Political Pressures Affect RMB/USD Exchange Rate? Studies of International Finance, No. 12, 26-34.

[12] Fatum, R., Hutchison, M.M. (2003) Is Sterilized Foreign Exchange Intervention Effective after All? An Event Study Approach. Economic Journal, 113, 390-411. http://dx.doi.org/10.1111/1468-0297.00122

[13] Pierdzioch, C. and Stadtmann, G. (2004) The Effectiveness of the Interventions of the Swiss National Bank-An Event-Study Analysis. Kiel Working Paper No. 1160, Kiel Institute for World Economics, 229-244.

[14] Fratzscher, M. (2008) Communication and Exchange Rate Policy. Journal of Macroeconomics, 30, 1651-1672. http://dx.doi.org/10.1016/j.jmacro.2008.07.002

\section{Submit or recommend next manuscript to SCIRP and we will provide best service for you:}

Accepting pre-submission inquiries through Email, Facebook, LinkedIn, Twitter, etc.

A wide selection of journals (inclusive of 9 subjects, more than 200 journals)

Providing 24-hour high-quality service

User-friendly online submission system

Fair and swift peer-review system

Efficient typesetting and proofreading procedure

Display of the result of downloads and visits, as well as the number of cited articles

Maximum dissemination of your research work

Submit your manuscript at: http://papersubmission.scirp.org/ 